\title{
The Factors Contributing to the Challenges with Apprenticeship in Ghana: Trainees' Perspective
}

\author{
Humphrey Danso and Richard Osei Kwadwo \\ Department of Construction \& Wood Technology Education, Akenten Appiah-Menka University of Skills \\ Training \& Entrepreneurial Development, Kumasi, Ghana \\ E-mail: hdanso@aamusted.edu.gh/dansohumphrey@yahoo.co.uk
}

\begin{abstract}
Apprenticeship has been the method of training the youth in acquiring employable skills in most developing countries. It provides an avenue for school dropouts to acquire skills leading to employment for sustainable livelihood. Apprenticeship plays a significant role in providing a skilled workforce and produces entrepreneurs, however, it is confronted with many challenges. This study, therefore, assessed the factors contributing to the challenges with an apprenticeship in Ghana, specifically from the trainees' perspective. A descriptive survey was employed with a stratified random sampling technique used to select 1200 participants for data collection using a questionnaire. The study identified ten key or extremely challenging factors such as; the quality of the training is controlled by masters, masters provide training schedule, the training involves only practical activities, the training includes entrepreneurial skills, the training includes customer care, the training involves the use of modern technology, the training included financial management skills, there are policies governing the duration of the training, equipment and tools used are modern, and policies governing the duration training. Six components were found to be the factors contributing to the challenges, including; training structure-related factors, contemporary technological-related factors, aid-related factors, recognition-related factors, funding-related factors and perception-related factors; and these factors correlate positively and significantly. It is recommended that the government of Ghana should help in providing training structure and resources to promote skills training for the youth to acquire sustainable employment.
\end{abstract}

Keywords: Apprenticeship, Apprentice, Challenges with apprenticeship, Entrepreneurs, Training

DOI: $10.7176 / \mathrm{JEP} / 12-30-02$

Publication date:October $31^{\text {st }} 2021$

\section{Introduction}

The impact of apprenticeship in the globe largely remains imperative and cannot be underestimated. Apprenticeship doubles as the backbone buttressing the formal workforce sector and providing employment opportunities especially for the youth (Baidoo, Tachie-Menson, Arthur and Asante 2020: Anokye and Afrane, 2014). Ghana boasts of a very good apprenticeship enterprise that enables young people to acquire skills that are geared towards self-employment (USAID, 2021). Ezenwakwelu, Egbosionu and Okwo (2019) echoed that apprenticeships act as a channel for providing the youth with technical and professional skills and more importantly, training them for self-employment. Apprenticeship has stood the test of time even long before the introduction of formal education in Ghana (Aidoo, 2018). It is still the most important training path that leads to self-employment especially among the youth in Ghana. ILO (2013) established that more than $80 \%$ of the labour force in Ghana is in the informal economy, and a significant portion acquires their skills through apprenticeship. Tagged as the most relevant source of skills training in Asia, South and Africa, apprenticeship systems continue to prevail in many countries (Ezenwakwelu et al., 2019). Ghana has identified itself in apprenticeship, mainly in trade areas such as dressmaking/tailoring, hairdressing, bakery/cookery, masonry, carpentry, electrical wiring/electronics, auto mechanics, welding, spraying, decoration, painting, vehicle driving.

Fundamentally, apprenticeship has been the method of training the youth in acquiring employable skills in Ghana and all over Africa for centuries (Ezenwakwelu et al., 2019). Typically, the traditional (unregulated) apprenticeship is the type practiced in Ghana (Aidoo, 2018). Darko and Lowe (2016) describe traditional apprenticeship as a low-cost method of skills training that provides learning opportunities to persons who have limited educational preparation for formal training and serves key groups such as the urban poor and rural populations. Eminently, apprenticeship has been patronized owing to the strengths in its practical skills, selffinancing, and self-regulation (Sonnenberg, 2012). Traditionally, apprentices acquire skills in their trade area by enrolling on an apprenticeship with master craftsmen who train them through work experience. Similarly, Ezenwakwelu et al. (2019) explained that apprentices acquire competencies through working for a master who assists them in learning the skills in return for labour at a specified duration. For instance, when the master plumber works with an apprentice, the intent is for the apprentice to eventually be able to offer the same service as the master (Kirchner \& London, 2021). Highly characterized with its dominance in the acquisition of employable skills as a means of livelihood for the youth (Sonnenberg, 2012), the apprenticeship system in Ghana has been a key part of the economy, as it compliments skills training and acquisition of human resources for the development 
of the nation (Anokye \& Afrane, 2014). Apprenticeship indeed plays a significant role in providing a skilled workforce for national development and produces entrepreneurs who start their businesses. It also provides an avenue for school dropouts to acquire skills leading to employment for livelihood.

Several studies have been conducted on an apprenticeship in Ghana (Bakker-Edoh \& Dzramedo, 2016; Tutu Ayentimi, Burgess \& Dayaram, 2018; Aidoo, 2018; Palmer, 2009; Anokye \& Afrane 2014; Baidoo et al., 2020; Donkor \& Mallet, 2006; Sonnenberg, 2012). Bakker-Edoh and Dzramedo (2016) studied the opportunities and challenges of the competencies of apprenticeship in relation to school-based training in just one municipality in Ghana. Tutu Ayentimi et al. (2018) used human capital theory to determine the skilled labour shortage in Ghana through a qualitative approach and found factors such as lack of regulations, training mismatch, underinvestment and outdated training programmes as the main causes of labour shortage. Aidoo (2018) investigated the apprenticeship of the visual art vocations as an attempt to formalize the apprenticeship in Ghana and found that the traditional apprenticeship in the visual art vocations is characterized by significant weaknesses in terms of quality of training and relevance. Palmer (2009) examine how to formalized the apprenticeship programme in Ghana, and concluded that the government should consider the ramifications of the activities under the national apprenticeship programme and upgrade the informal apprenticeship. Anokye and Afrane (2014) examined the institutional dynamics, processes and challenges confronting the apprenticeship system in Ghana. They found that the apprenticeship system provides an avenue for 33 to $42 \%$ of school dropouts, and the master craftsmen who provide the training have a weak theoretical background and also face financial challenges. Baidoo et al. (2020) investigated the processes, challenges and nature of the informal jewellery apprenticeship in Ghana, and found that the training system is unstructured as the master craftsmen design and instruct the training. Donkor and Mallet (2006) proposed a model to address the challenges faced with the apprenticeship in Ghana, which includes on-site training and off-site training. Sonnenberg (2012) studied the traditional apprenticeship in both Ghana and Senegal. Hardy, Mbiti, McCasland and Salcher (2019) investigated the effects of government-financed apprenticeship programme aimed at reducing unemployment in Ghana and found that the apprenticeship programme contributed to the shift of youth from wage-based work to self-employment.

From the aforementioned studies, it is evident that most studies concentrated on the nature and the processes of apprenticeship in Ghana. Few studies focused on the challenges of apprenticeship in Ghana, and those considered the challenges in particular trade areas such as jewellery and visual art and from the trainers' and managers' perspective. There is limited research on the challenges confronting the apprenticeship in Ghana covering all the regions and the various trade areas from the perspective of the trainees. This study, therefore, seeks to assess the factors contributing to the challenges with an apprenticeship in Ghana, specifically from the trainees' perspective.

\section{Literature Review}

Apprenticeship has long existed as the only mode of skills training for craft before the emergence of formal education in Ghana (Aidoo, 2018). It is the predominant skills training model and is usually associated with the informal sector in many African countries. Apprenticeship is the main entry point for dropouts from schools and also for some graduates from pre-secondary schools in African countries (World Bank, 2005). According to Aidoo (2018), about 55\% of graduates from junior high school (JHS) are unable to enter into senior high school (SHS) because of inadequate access. This makes apprenticeship an important mode of training especially for the youth to gain employment and have a sustainable livelihood. The growing concern about the high number of JHS graduates unable to access further education has led to the demand for a national apprenticeship programme (NAP) to be established and regulate the apprenticeship system in Ghana (Palmer, 2009). This is because apprenticeship offers several benefits.

Apprenticeship provides numerous benefits to both the apprentice and society in general. Apprenticeship ensures a high supply of skilled workforce for different trade areas. Young people who are trained on the job usually exhibit loyalty to the companies that trained them with their skills (Bakker-Edoh \& Dzramedo, 2016). The focus of apprenticeship is to impart young people with knowledge and skills to build a career (Baidoo et al., 2020). In some countries, the employers who participate in apprenticeship programmes are given tax exemptions and other benefits. Several apprenticeship programmes accept young people, including those who do not complete their education to develop skills that may provide them with living employment (Anamuah-Mensah, 2002). Apprenticeship also benefits young people who finished their education but want to acquire practical skills to start their businesses. Apprenticeship is well-known to be extremely practical and useful in offering skills that are needed to young people for the world of work. The training costs less than formal education and is also accessible to more marginal societal groups than the formal training system (Aidoo, 2018). Besides these benefits of apprenticeship, there are also some challenges that affect the system.

Beneficiaries of apprenticeship encounter challenges extending from marital problems, lack of support, absence of training manuals, insufficient training tools, inadequate infrastructure facilities, too long a training period (Ezenwakwelu et al., 2019; Anokye \& Afrane, 2014; Alhassan, 2016;). Regardless of its long duration, 
apprenticeship generates low income and lacks certification (Sonnenberg, 2012; Fields, 1990; King, 1990). As if not enough, apprenticeship pathways are impeded with a varied chain of instances such as low completion rates, lack of structured training, time-served rather than competency acquisition (Alhassan, 2016). Parallel to the preceding, majority of those who end up acquiring skills through an apprenticeship is not able to set up their businesses and function effectively. In many cases, apprenticeship does not follow the rules of decent work, for instance, trainees are made to work long hours with little or no break which negatively affects their health (Ezenwakwelu et al., 2019). According to Palmer (2005), some of the challenges associated with an apprenticeship in Ghana include unclear organizational structure, lack of formal curriculum, lack of government ministerial control, and lack of sponsorship for the training. Molz (2015) identified some challenges with an apprenticeship as unsafe working conditions, little or no social protection, long working hours, inadequate allowances or wages, and gender imbalance. According to Anokye and Afrane (2014), it is difficult to compare different apprentices in the same trade area who were trained by different masters because of the inconsistency in the teaching and learning methodologies and the unstructured learning environment.

\section{Methodology}

The study employed a descriptive survey in arriving at its findings. A population of apprentices in their respective apprenticeship practices all over the sixteen regions of Ghana was engaged. Adopting the stratified random sampling technique, participants were selected from all the regions. Communities, where participants were involved attending to the various trades of apprenticeship, were put into strata (groups). A simple random sampling technique was used to obtain the sample from each community, which was helpful to capture the greater proportion of the participants (Taherdoost, 2018). As the main data collection instrument, a questionnaire was selfadministered to the participants sampled across all the sixteen regions in Ghana. the majority of the respondents were guided through the questionnaire items to better help them respond appropriately due to their low level of education or not having any formal education. The questionnaire was used to obtain data on the demographic characteristics of respondents as well as the challenges associated with the apprenticeship in Ghana, particularly from the trainees' perspective. The items used in the questionnaire were adapted from the literature. The responses to the items in the questionnaire were based on a 5-Point Likert scale from strongly disagree (1) to strongly agree (5). Meeting the recommended Cronbach's alpha threshold of 0.7 (Straub, Boudreau and Gefen, 2004), the reliability of the items was ensured after pre-testing of the question which yielded a Cronbach's alpha of 0.876 . Seventy-five questionnaires were sent to each region making a total of 1200, out of which 1042 were recovered successfully. This represents a response rate of $86.83 \%$. As suggested by Moser and Kalton (1971) in Nyantakyi et al. (2020), a result from a survey with a return rate lower than the range of 30-40\% is esteemed biased or of little value. The data subsequently were subjected to descriptive analysis, factor analysis and correlation analysis with the help of statistical package for social sciences (SPSS) version 25.

Table 1. Demographic characteristics of respondents

\begin{tabular}{llcc}
\hline Characteristics & Category/Option & Frequency & Percentage \\
\hline Gender & Male & 638 & 62.9 \\
& Female & 376 & 37.1 \\
& Total & 1014 & 100 \\
\hline Educational level & Non-educated & 81 & 8.0 \\
& Primary & 59 & 5.8 \\
& JHS & 330 & 32.5 \\
& Tech./Voc. Sch. & 200 & 19.7 \\
SHS & 235 & 23.2 \\
& Others & 109 & 10.8 \\
& Total & 1014 & 100 \\
\hline Trade area & Dress Making/Tailoring & 15.3 \\
& Hair Dressing & 11.1 \\
& Bakery/Cookery & 113 & 6.9 \\
& Masonry & 70 & 8.2 \\
& Carpentry & 83 & 14.2 \\
& Electrician & 144 & 8.7 \\
Auto Mechanics & 88 & 6.3 \\
& Welding & 64 & 6.5 \\
& Spraying & 66 & 3.1 \\
& Decoration & 31 & 3.9 \\
Painting & 40 & 3.4 \\
& Vehicle Driving & 34 & 4.4 \\
& Others & 45 & 8.0 \\
Total & 81 & 100 \\
\hline
\end{tabular}




\begin{tabular}{llcc}
\hline & & & \\
\hline Characteristics & Category/Option & Frequency & Percentage \\
\hline Number of years in training & $<$ 1 year & 91 & 9.0 \\
& 1 year & 148 & 14.6 \\
& 2 years & 263 & 25.9 \\
& 3 years & 330 & 32.5 \\
& 4 years & 87 & 8.6 \\
& > 4 years & 95 & 9.4 \\
& Total & 1014 & 100 \\
\hline
\end{tabular}

\section{Results and Discussions}

\subsection{Demographic characteristic of respondents}

Table 1 shows the key characteristics of respondents such as their gender, educational level, trade area, and years in training. the majority of the respondents were male $(62.9 \%)$ as compared with the female $(37.1 \%)$. More than half of the respondents $(92 \%)$ had received some level of education such as been in primary school, junior high school, technical or vocational school, senior high school and others, while $8 \%$ had no formal education. Relative to the trade areas of respondents, $15.5 \%$ were into dressmaking/tailoring, carpentry $(14.2 \%)$, hairdressing $(11.1 \%)$, electrician $(8.7 \%)$, masonry $(8.2 \%)$, bakery/cookery $(6.9 \%)$, welding $(6.5 \%)$, auto mechanics $(6.3 \%)$, vehicle driving (4.4\%), decoration (3.9\%), painting (3.4\%), spraying (3.1\%) and others $(8.0 \%)$ followed accordingly. In reviewing the number of years spent by respondents in their respective fields of training, a greater majority $(91.0 \%)$ had more than a year experience against those with less than just a year (9.0\%).

\subsection{Key challenges with an apprenticeship in Ghana}

In authenticating the key challenges with an apprenticeship in Ghana, respondents' responses were descriptively analysed, ranked and interpreted as shown in Table 2. Indicative of their responses, the outcome of the analysis was centered on limits that clearly defined the extent to which these challenges were associated with an apprenticeship in Ghana. In this sense, the limits were defined as; mean $\geq 3.50$ were categorized as "Extremely challenging", mean 3.0 - 3.49 were labeled "Very challenging", mean $2.5-2.99$ were named "Relatively challenging", mean $2.1-2.49$ were labeled as "Challenging" and mean $\leq 2.0$ classified as "Less challenging". These limits were important as they indicated the extent to which the challenges were alarming or not.

As shown in Table 2, the first ten items fell within the threshold of "Extremely challenging". The next eight variables settled for "Very challenging", with the subsequent seven, six and four items each coming under "Relatively challenging", "Challenging" and "Less challenging" respectively by merit of their mean values. Accordingly, the ten extremely challenging factors were the quality of the training is controlled by my master, masters provide their own training schedule, the training involves only practical activities, the training includes entrepreneurial skills, the training includes learning customer care, the training involves the use of modern technology, the training included financial management and planning skills, there are policies governing the duration of my training, the equipment and tools used in the training are modern, and policies governing the duration of my training. The very challenging category gave factors such as; there are policies governing the structure of my training, there are policies governing the management of my training, the training is funded by my parents, we learn with the latest technology in our training, there are policies governing the certification of my training, there is a clear plan structure of the training, I will receive a certificate from my master upon completion of training, and we sometimes use the internet to search for information and activities in our training.

Table 2. Key challenges with apprenticeship in Ghana

\begin{tabular}{lcccc}
\hline Factors & Mean & Std Dev & Rank & Remark \\
\hline The quality of the training is controlled by my master. & 4.09 & 1.176 & 1 & Ex. challenging \\
Masters provide their own training schedule. & 4.06 & 1.151 & 2 & Ex. challenging \\
The training involves only practical activities. & 3.83 & 1.337 & 3 & Ex. challenging \\
The training includes entrepreneurial skills. & 3.78 & 1.118 & 4 & Ex. challenging \\
The training includes learning costumer care. & 3.76 & 1.097 & 5 & Ex. challenging \\
The training involves the use of modern technology. & 3.58 & 1.284 & 6 & Ex. challenging \\
The training included financial mgt. and planning skills & 3.56 & 1.154 & 7 & Ex. challenging \\
Modern machines are used in the training. & 3.56 & 1.262 & 8 & Ex. challenging \\
The equipment and tools used in the training are modern. & 3.56 & 1.262 & 9 & Ex. challenging \\
There are policies governing the duration of my training. & 3.54 & 1.361 & 10 & Ex. challenging \\
There are policies governing the structure of my training. & 3.49 & 1.278 & 11 & V. challenging \\
There are policies governing the management of my training. & 3.49 & 1.261 & 12 & V. challenging \\
The training is funded by my parents. & 3.48 & 1.563 & 13 & V. challenging \\
We learn with the latest technology in our training. & 3.47 & 1.349 & 14 & V. challenging \\
There are policies governing the certification of my training & 3.45 & 1.331 & 15 & V. challenging
\end{tabular}




\begin{tabular}{|c|c|c|c|c|}
\hline Factors & Mean & Std Dev & Rank & Remark \\
\hline There is a clear plan structure of the training. & 3.45 & 1.313 & 16 & V. challenging \\
\hline I will receive certificate from my master on completio & 3.44 & 1.425 & 17 & V. challenging \\
\hline $\begin{array}{l}\text { We sometimes use internet to search for information and activities } \\
\text { in our training. }\end{array}$ & 3.31 & 1.429 & 18 & V. challenging \\
\hline $\begin{array}{l}\text { I will be accredited by recognized body upon completion of } \\
\text { training. }\end{array}$ & 2.95 & 1.349 & 19 & Challenging \\
\hline The training includes theory modules. & 2.83 & 1.451 & 20 & Challenging \\
\hline $\begin{array}{l}\text { I will receive certificate from any recognized awarding body upon } \\
\text { completion of training. }\end{array}$ & 2.83 & 1.441 & 21 & Challenging \\
\hline The quality of the training is assessed by external body. & 2.78 & 1.408 & 22 & Challer \\
\hline The training is fund & 2.57 & 1.362 & 23 & Challenging \\
\hline controlled by any recognized body. & 2.56 & 1.388 & 24 & Challenging \\
\hline I am & 2.52 & 1.270 & 25 & Challenging \\
\hline I will be accredited by government upon completion of training. & 2.49 & 1.324 & 26 & Re. challenging \\
\hline $\begin{array}{l}\text { I will receive certificate from government on completion of } \\
\text { training. }\end{array}$ & 2.49 & 1.529 & 27 & $\mathrm{Be}$ sh \\
\hline The training is funded by my master & 2.45 & 1.432 & 28 & Re. challenging \\
\hline The traini & 2.42 & 1.352 & 29 & Re. challenging \\
\hline Gove & 2.28 & 1.395 & 30 & Re. challenging \\
\hline trolled by government. & 2.13 & 1.379 & 31 & Re. challenging \\
\hline pon completion of training. & 2.09 & 1.319 & 32 & Le. challenging \\
\hline The training is funded by some NGO. & 1.92 & 1.214 & 33 & Le. challenging \\
\hline The training is funded by my boyfriend or gi & 1.83 & 1.182 & 34 & Le. challenging \\
\hline The training is funded by government & 1.82 & 1.291 & 35 & Le. challenging \\
\hline
\end{tabular}
Ex. (Extremely); V (Very); Le (Less); Extremely challenging ( $\geq 3.50)$; Very challenging (3.0 - 3.49); Relatively challenging (2.5 - 2.99); Challenging $(2.1-2.49)$; Less challenging $(\leq 2.0)$

\subsection{Assessing the factors contributing to the challenges with an apprenticeship in Ghana}

Factor analysis was used to assess the factors contributing to the challenges with an apprenticeship in Ghana. Table 3 presents the total variance explaining the underlying factors. From the result, six factors were identified. The most commonly used rule of significance; the eigenvalue of 1 or greater, was used to attain these six factors. Also, the scree plot upon close examination similarly confirmed these same number of factors as shown in Figure 1. As a rule of thumb, the six factors explained total variance cumulating about $64 \%$ of the total variance. The variance explained by these factors were $30.402 \%, 9.235 \%, 8.226 \%, 6.580 \%, 5.355 \%$ and $4.291 \%$. The designated components with their associate factor loadings representing the challenges with an apprenticeship in Ghana are presented in Table 4. The Varimax method of rotation was adopted to align the factors under their respective components. As a prerequisite, the Kaiser-Meyer-Olkin Measure of Sampling Adequacy (KMO) and Bartlett's Test of Sphericity was carried out on the data to substantiate the use of factor analysis as shown in Table 5. In effect, the KMO gave a value of 0.910, Bartlett's test, in turn established a sense of high relationships among the variables (Chi-square $=13981.852, \mathrm{df}=378, \mathrm{p}<0.000$ ) thus, signifying the adequacy and suitability of applying this tool.

Table 3. Total Variance explained

\begin{tabular}{lllllll}
\hline \multirow{2}{*}{ Component } & \multicolumn{2}{l}{ Extraction Sums of Squared Loadings } & \multicolumn{3}{c}{ Rotation Sums of Squared Loadings } \\
& Total & \% of Variance & Cumulative \% & Total & \% of Variance & Cumulative \% \\
\hline 1 & 8.513 & 30.402 & 30.402 & 4.186 & 14.952 & 14.952 \\
2 & 2.586 & 9.235 & 39.637 & 4.050 & 14.466 & 29.418 \\
3 & 2.303 & 8.226 & 47.864 & 3.762 & 13.437 & 42.855 \\
4 & 1.842 & 6.580 & 54.443 & 2.772 & 9.900 & 52.755 \\
5 & 1.500 & 5.355 & 59.799 & 1.785 & 6.376 & 59.131 \\
6 & 1.201 & 4.291 & 64.089 & 1.388 & 4.958 & 64.089 \\
\hline
\end{tabular}

Extraction Method: Principal Component Analysis 


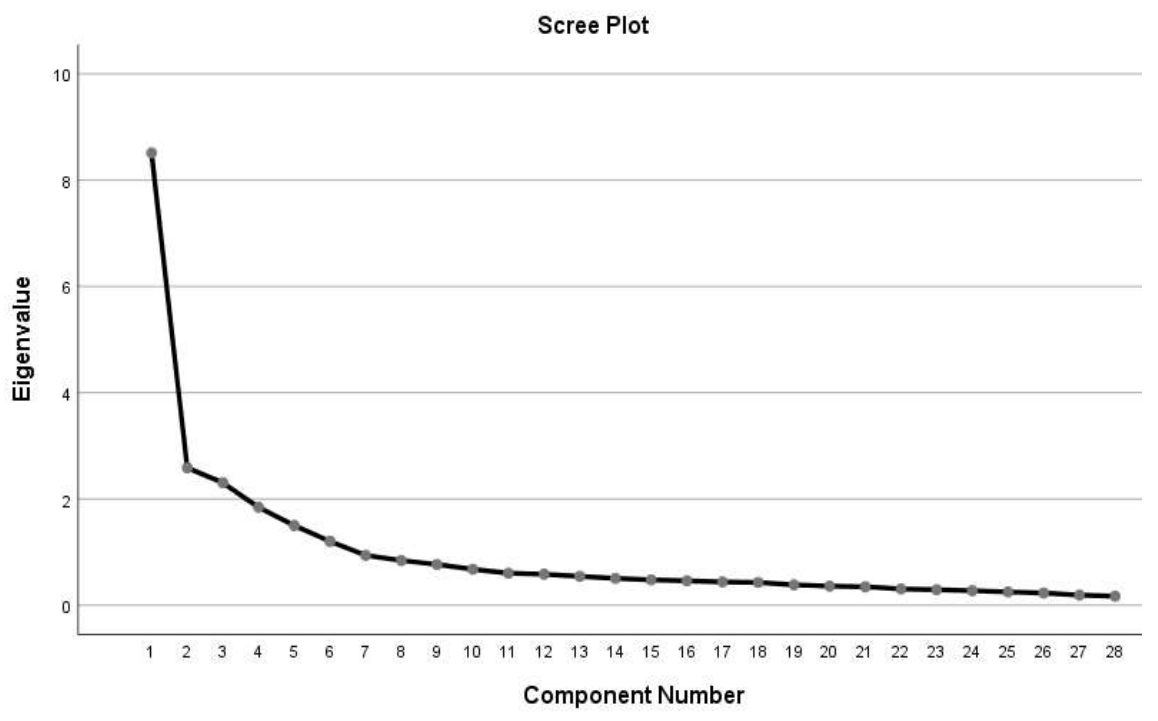

Figure 1. Scree Plot

Table 4. Factors contributing to challenges with Apprenticeship in Ghana

\section{Factors}

There are policies governing the structure of my training.

There are policies governing the management of my training.

There are policies governing the duration of my training.

There is a clear plan structure of the training.

The training included financial mgt. and planning skills

The training includes entrepreneurial skills.

The training includes learning costumer care.

There are policies governing the certification of my training.

Modern machines are used in the training.

The equipment and tools used in the training are modern.

My training involves the use of modern technology.

We learn with the latest technology in our training.

We sometimes use internet to search for information and activities in our training.

The quality of the training is controlled by government.

Government provides approved training modules.

The training is funded by government

I will receive certificate from government upon completion of training.

I will be accredited by government completion of training.

The training includes theory modules.

I will receive certificate from any recognized awarding body upon completion of training.

The quality of training is controlled by any recognized body.

I will be accredited by any recognized body upon completion of training.

The quality of the training is assessed or evaluated by external body.

The training is funded by my brother or sister.

The training is funded by my family member.

The training is funded by my parents.

I am unaware of quality control of the training.

Components

1

0.812

0.793

0.754

0.687

0.631

0.616

0.582

0.558 
Table 5. KMO and Bartlett's test

Kaiser-Meyer-Olkin Measure of Sampling Adequacy.

Bartlett's Test of Sphericity
Sig.

$\begin{array}{ll}\text { Approx. Chi-Square } & 0.910 \\ \text { df } & 13981.852 \\ \text { Sig. } & 378 \\ & 0.000\end{array}$

As can be seen from Table 4, eight factors aggregated unto component one and were named Training structure-related factors. Component two had five factors and was named as Contemporary technological-related factors. Component three recording six factors which were labeled as Aid-related factors. Four factors loaded unto component four as Recognition-related factors, with components five and six loading three factors each as Funding-related factors and Perception-related factors respectively.

4.3.1 Component 1: Training structure-related factors

The principal component accounted for $14.952 \%$ of the total variance with eight factors loading unto it. The factors included; there are policies governing the structure of my training, there are policies governing the management of my training, there are policies governing the duration of my training, there is a clear plan structure of the training, the training included financial management and planning skills, the training includes entrepreneurial skills, the training includes learning costumer care, and there are policies governing the certification of my training. In his study, Alhassan (2016) found that there is no structured training system for apprentices under training. He further revealed that there were no prepared training manuals used for the training. According to Palmer (2009) and Baidoo et al. (2020), the lack of regulatory framework enforcement consequently has led to the exploitation of the training process by some masters. There are no government control measures to regulate the apprenticeship system, which has resulted in haphazard nature of system and therefore made it less attractive to the youth. Fajobi, Olatujoye, Amusa and Adedoyin (2017) were of the view that most of the masters lack the skills of teaching which leads to the lack of the ability to sustain the interest of the apprentice for successful completion of the training. Alhassan (2016) postulated that, there is no prescribed period of training resulting in an unclear period of time for the completion of the training. According to Sonnenberg (2012), this results in prolong training time and there is also the lack of certification upon completion of the training. Ackah, Opoku and Wong (2020) admitted that, the low level of skill resulting from inadequate and low quality training have become one of the major challenges limiting apprenticeship. Apprenticeship is the best way to acquire skills, however, the training is not properly structured. From the foregoing, it is obvious that there is a major challenge with the structure of training for apprenticeship in Ghana.

4.3.2 Component 2: Contemporary technological-related factors

Component two had the principal component describing $14.466 \%$ of the total variance. Constituting this component were the factors; modern machines are used in the training, the equipment and tools used in the training are modern, my training involves the use of modern technology, we learn with the latest technology in our training and we sometimes use internet to search for information and activities in our training. Bakker-Edoh and Dzramedo (2016) disclosed that, the master's update and upgrade on the technicalities, technological competencies needed for the making artefacts that can compete favorable in the global marketplace more often than not is stifled. The rippling effects conversely is suffered by the apprentice. Fajobi et al. (2017) strongly advocated that, outdated approach and techniques use in apprenticeship system must be checked. The essential tools and equipment that meet the modern technological needs are not used by the master craftsmen in training the apprentice (Ezenwakwelu et al., 2019). This implies that the adoption of contemporary technological tools in the training of apprentice in Ghana is a major challenge.

\subsubsection{Component 3: Aid-related factors}

Under this premise, the principal component explained $13.437 \%$ of the principal component. Loading unto this component were the factors; the quality of the training is controlled by government, government provides approved training modules, the training is funded by government, I will receive certificate from government upon completion of training, I will be accredited by government upon completion of training and the training includes theory modules. Fajobi et al. (2017) argued that, due to unavailability of some help such as career counseling, exposure to the issues in the world of work and limited theoretical knowledge, the apprentices often make mistake in their career choices. Buttressing this, Biney-Aidoo, Antiaye and Oppong (2013) noted that, the attitude of some of the apprentices toward work prevents master craftsmen from teaching them certain vital skills. He further explained that most of them go into apprenticeship by chance or are forced by their parents or guardians without having any interest. Therefore, they do not pay much attention to the master-craftsmen and may graduate without being equipped with the necessary skills. Ezenwakwelu et al. (2019) posited that majority of the apprentices have no financial support which leads to some of the apprentices abandoning the training halfway and also leads to lackadaisical attitude of the apprentices. In a study by Alhassan (2016), he discovered that that there is the lack of aid such as training manuals provided to the apprentice during training. In general, the aid provided by both government and parents to the apprentice to support their training is a challenge. The kind of aid provided by government and parent for young people in formal education system is not the same for the youth in apprenticeship. 


\subsubsection{Component 4: Recognition-related factors}

Defining $9.9 \%$ of the total variance, this component had four factors loading unto it. These were; I will receive certificate from any recognized awarding body upon completion of training, the quality of the training is controlled by any recognized body, I will be accredited by any recognized body upon completion of training and the quality of the training is assessed or evaluated by external body. Apprenticeship is mostly concerned with functional literacy; making the youth functional in the society other than the award of a certificate (Olivera, Troyano \& Aguilera, 2020). Skills acquisition and to be productive in the society overrides certification that is professed. In highlighting this assertion, Udu (2015) reiterated that certificates are not issued for successful completion of the training, rather there is usually a celebration to void the tutelage agreement. Many years of hard work and discipline under the authority of the master is the key to the young apprentice's training and learning process. One essential trait of apprenticeship model is that, there is hardly any entry requirement and stipulation period of completion as such is dependent on the effort of the apprentice (Mbiti, McCasland, Hardy, Cole, Enriquez \& Salcher, 2019). This invariably leaves a challenge in certification. According to Adekola (2013), the apprentices in apprenticeship are considered as never do well people and therefore not given the needed respect as compared to their counterparts in the formal school system. This implies that recognition in terms of certification, accreditation and respect for apprentices is a challenge with apprenticeship.

\subsubsection{Component 5: Funding-related factors}

The principal component resolved $6.376 \%$ of the total variance with three factors loading unto it. These comprised; the training is funded by my brother or sister; the training is funded by my family member and the training is funded by my parents. One of the major problems with the apprenticeship in emerging countries is funding. Financial problem, mostly proves very challenging to the success of the apprenticeship (Ezenwakwelu et al., 2019). Nkechi, Ikechukwu and Okechukwu (2012) stipulated that, the lack of funding creates a major challenge to apprenticeship in developing countries. The low income level of most parents and guardians of the apprentices in apprenticeship makes it difficult for successful completion of the training. Fajobi et al. (2017) were categorical that corruption has made funds meant for development projects such as apprenticeship have been diverted, causing financial challenge to the survival of apprenticeship. Apprenticeship usually involve an upfront fee which the youth and their parents may not have. Apprenticeship suffer from funding especially with buying of materials and basic tools, and upkeep of the apprentice in terms of feeding, accommodation and transportation cost. Funding of apprenticeship remains a challenge.

4.3.6 Component 6: Perception-related factors

Component six explained $4.958 \%$ of the total variance and also with three factors accumulated unto it. The factors involved are; I am unaware of quality control of the training; I will not receive any certificate upon completion of training, and the training involves only practical activities. As explained by Alhassan (2016), there is no prescribed period of training for apprentices and therefore, the apprentices have to remain in the training until all the required competencies are acquire. This means the apprentices work under undefined period, and not sure when the training will be completed. Fox and Gaal (2008) were blunt on the fact that, apprenticeship was viewed as a means of surviving and coping mechanism for the youth who drop out of school remaining with the only option of learning a trade and to settle in the informal economy. According to Bakker-Edoh and Dzramedo (2016), apprenticeship is of long duration and result in a low pay, coupled with the lacks certification. The unclear nature of apprenticeship always leads to perceptions in the training which a major challenge.

\subsection{Relationship between the principal components on the factors contributing to challenges with Apprenticeship in Ghana}

To be explicit and bolster the facts regarding the factors contributing to challenges with apprenticeship in Ghana, a correlation assessment was performed on the principal components obtained through the use of correlation matrix. Liu (2013), posits that correlation is performed to test the degree to which two variables co-relate. In the quest to establish the desired outcome, a two tailed bivariate correlation analysis was performed (see Table 6). This demonstrates the relationship between variables such that, they can be positive, negative or have no relationship at all. The level of significance was set at $\left(\mathrm{r}_{\mathrm{s}} \geq 0.1, \mathrm{p}<0.01\right)$.

Table 6. Relationship between the principal components on the factors contributing to challenges with apprenticeship in Ghana

\begin{tabular}{lllllll}
\hline Components & 1 & 2 & 3 & 4 & 5 & 6 \\
\hline 1 Training structure-related factors & 1.000 & & & & & \\
2 Contemporary technological-related factors & $0.473^{* *}$ & 1.000 & & & & \\
3 Aid-related factors & $0.375^{* *}$ & $0.404^{* *}$ & 1.000 & & & \\
4 Recognition-related factors & $0.454^{* *}$ & $0.399^{* *}$ & $0.516^{* *}$ & 1.000 & & \\
5 Funding-related factors & $0.155^{* *}$ & -0.011 & -0.022 & $0.101^{* *}$ & 1.000 & \\
6 Perception-related factors & $0.358^{* *}$ & 0.032 & -0.035 & 0.046 & $0.096^{* *}$ & 1.000 \\
\hline$* *$ Correlation is significant at the 0.01 level (2-tailed). & & & & & \\
\hline
\end{tabular}


As shown in the correlation matrix result (Table 6), the highest correlation was found between recognitionrelated factors and aid-related factors $\left(\mathrm{r}_{\mathrm{s}} \geq 0.516, \mathrm{p}<0.01\right)$. This in essence implies that an impact in recognitionrelated factors invariably will influence aid-related factors positively. Alhassan (2016) in his work alerted that, people who go into apprenticeship are predominantly school dropouts and those with no formal education, and therefore hinders the need to invest in them. Tatum (2003) questioned why the need for such interventions as the majority of those who end up acquiring skills through an apprenticeship is not able to set up their own shops and function effectively.

Again, training structure-related factors correlated positively with contemporary technological-related factors $\left(\mathrm{r}_{\mathrm{s}} \geq 0.473, \mathrm{p}<0.01\right)$, aid-related factors $\left(\mathrm{r}_{\mathrm{s}} \geq 0.375, \mathrm{p}<0.01\right)$, recognition-related factors $\left(\mathrm{r}_{\mathrm{s}} \geq 0.454, \mathrm{p}<0.01\right)$, funding-related factors $\left(\mathrm{r}_{\mathrm{s}} \geq 0.155, \mathrm{p}<0.01\right)$ and perception-related factors $\left(\mathrm{r}_{\mathrm{s}} \geq 0.358, \mathrm{p}<0.01\right)$. Achieving such a feat will mean that, a positive change in the training structure-related factors will in turn cause a change in contemporary technological-related factors, aid-related factors, funding-related factors and perception-related factors positively. According to Ezenwakwelu et al. (2019), the inconsistency in apprenticeship programs remains a challenge. As some apprenticeship programs are non-functional, the others are on the close to folding up. At times, the changes of government result in the neglect of existing apprenticeship programs. Alhassan (2016) explained that is the lack of resources such as training manuals and financial support for apprentices which leads to the apprentices abandoning the training.

Further, contemporary technological-related factors similarly had a positive relation with aid-related factors $\left(r_{s} \geq 0.404, p<0.01\right)$ and recognition-related factors $\left(r_{s} \geq 0.399, p<0.01\right)$. Funding-related factors also recorded a positive correlation with recognition-related factors $\left(r_{s} \geq 0.101, p<0.01\right)$. However, funding-related factors yielded a negative correlation with contemporary technological-related factors $\left(\mathrm{r}_{\mathrm{s}} \geq-0.011, \mathrm{p}<0.01\right)$ and aidrelated factors $\left(\mathrm{r}_{\mathrm{s}} \geq-0.022, \mathrm{p}<0.01\right)$. This was equally seen between perception-related factor and aid-related factors.

\section{Conclusion}

This study aimed at assessing the factors contributing to the challenges with an apprenticeship in Ghana, specifically from the trainees' perspective. The key challenges with an apprenticeship, the factors contributing to the challenges with an apprenticeship, and the relationship between the principal components on the factors contributing to challenges with an apprenticeship in Ghana were determined. The study identified ten key or extremely challenging factors such as; the quality of the training is controlled by my master, masters provide their own training schedule, the training involves only practical activities, the training includes entrepreneurial skills, the training includes learning customer care, the training involves the use of modern technology, the training included financial management and planning skills, there are policies governing the duration of my training, the equipment and tools used in the training are modern, and policies governing the duration of my training. Six components were found to be the factors contributing to the challenges. These were training structure-related factors, contemporary technological-related factors, aid-related factors, recognition-related factors, fundingrelated factors and perception-related factors. A positive and significant correlation was found between recognition-related factors and aid-related factors; between training structure-related factors and (contemporary technological-related factors, aid-related factors, recognition-related factors, funding-related factors, and perception-related factors); and between contemporary technological-related factors and (aid-related factors, and recognition-related factors). The study, therefore, concludes that several factors contribute to the challenges with an apprenticeship in Ghana, and they can be categorized as training structure-related factors, contemporary technological-related factors, aid-related factors, recognition-related factors, funding-related factors, and perception-related factors; and these factors correlate positively and significantly. It is recommended that the government of Ghana and parents should help in providing training structure, modern tools and equipment, funding, and recognition that apprenticeship deserves to promote skills training for the youth to acquire sustainable employment. Future studies should consider assessing the perception of the general public on the benefits and challenges of apprenticeship.

\section{References}

Ackah, C., Opoku, K. \& Wong, B. (2020). Cost-Benefit Analysis of Skill Development Interventions in Ghana. Ghana Priorities, Copenhagen Consensus 1-27, https://www.copenhagenconsensus.com/sites/default/files/gp_a4_youth_unemployment_final.pdf

Adekola, G. (2013). Traditional apprenticeship in the old Africa and its relevance to contemporary work practices in modern Nigerian communities. British Journal of Education, Society and Behavioral Science, 3, 397-406.

Aidoo, J. B. K. (2018). The Status of Visual Art Apprenticeship Training in Ghana. Journal of Education and Practice, 9(1), 46-55.

Alhassan, M. (2016). The Major Constraints Militating Against Apprenticeship Training Schemes in the Informal Sector of Ghana: The Case of Tamale Metropolis. International Journal of Economics, Commerce and 
Management, 4(1), 615-631.

Anamuah - Mensah, J. (2002). Meeting the Challenges of Education in the Twenty-First Century: Report of the President's Committee on Review of Education in Ghana. https://searchworks.stanford.edu/view/5530562

Anokye, P. A. \& Afrane, S. K. (2014). Apprenticeship Training System in Ghana: Processes, Institutional Dynamics and Challenges. Journal of Education and Practice, 5(7), 130-141.

Biney-Aidoo, V., Antiaye, E. \& Oppong, J. A. (2013). An Assessment of the Apprenticeship System as a Means of Acquiring Sewing Skills in Ghana. Developing Country Studies, 3(11), 145-152.

Bakker-Edoh, D. \& Dzramedo, B. E. (2016). Competency of Apprenticeship and School Trained Fashion Designers: Its Opportunities and Challenges within the New Juaben Municipality, Ghana. ADRRI Journal of Arts and Social Sciences, Ghana: 13(10), 1-14.

Baidoo, M. K., Tachie-Menson, A., Arthur N.A. P. \& Asante, E. A. (2020). Understanding Informal Jewellery Apprenticeship in Ghana: Nature, Processes and Challenges. International Journal for Research in Vocational Education and Training, 7(1), 45-66, https://doi.org/10.13152/IJRVET.7.1.3

Darko, E., \& Löwe, A. (2016). Ghana's construction sector and youth employment. ODI Working Paper. Overseas Development Institute, 1-34, https://cisp.cachefly.net/assets/articles/attachments/63049_10771.pdf

Donkor, F. \& Mallet, J. (2006). Enhancing Apprenticeship Training in Ghana through Distance Learning. The Fourth Pan Commonwealth Forum on Open Learning, 2006, 1-6.

Ezenwakwelu, C. A., Egbosionu, N. A. \& Okwo, H. U. (2019). Apprenticeship training effects on entrepreneurship development in developing economies. Academy of Entrepreneurship Journal, 25(1), 1-21.

Fajobi, T. A., Olatujoye, O. O., Amusa, O. I. \& Adedoyin, A. (2017). Challenges of Apprenticeship Development and Youths Unemployment in Nigeria. Sociology and Criminology, 5(2), 1-8, doi:10.4172/23754435.1000172

Fox, L. \& Gaal, M. S. (2008). Working Out of Poverty; Job Creation and the Quality of Growth in Africa. Africa Region, The International Bank for Reconstruction and Development / The World Bank, Washington, D.C.

Hardy, M., Mbiti, I., McCasland., J. \& Salcher., I. (2019). The Apprenticeship-to-Work Transition Experimental Evidence from Ghana. Policy Research Working Paper 8851, World Bank Group.

International Labour Office (ILO), (2013). Learning and earning: overcoming low education through skill development. Geneva: ILO.

Kirchner, M. \& London, M. (2021). The Co-Created Classroom: Enhancing Students' Professional Identity through a Teaching Apprentice Assignment. College Teaching. 1-13, https://doi.org/10.1080/87567555.2021.1915235

Liu, J. (2013). Correlation Among Different Variables and Life Expectancy. Undergraduate Journal of Mathematical Modeling: One + Two, 3(2), https://doi.org/10.5038/2326-3652.3.2.2

Mbiti, I., McCasland, J., Hardy, M., Cole, K., Enriquez, M. \& Salcher, I. (2019). Training for success: targeting and incentives in apprenticeship training in Ghana. International Initiative for Impact Evaluation. 3ie Grantee Final Report.

Molz, A. (2005). Delivering TVET through quality apprenticeship. Virtual conference on the UNESCO-UNEVOC e-Forum. 1-6, https://unevoc.unesco.org/e-forum/BackgroundNote-VC-Apprenticeship-Molz.pdf

Nkechi, A., Ikechukwu, E. J. E. \& Okechukwu, U. F. (2012). Entrepreneurship development and employment generation in Nigeria: Problems and prospects. Universal Journal of Education and General Studies, 1(4), 88102.

Nyantakyi, E. K. (2020). Differential Pricing of Concrete Products within the Ghanaian Construction Industry. 9(5), 135-141. https://doi.org/10.5923/j.ijcem.20200905.01

Olivera, H. C. M., Troyano, A., \& Aguilera, X. (2020). Functional literacy: more than an apprenticeship, a life experience. Praxis Educativa, 24(01), 1-9. doi: 10.19137/praxiseducativa-2020-240111

Palmer, R. (2009). Formalising the informal: Ghana's National Apprenticeship Programme. Journal of Vocational Education \& Training, 61(1), 67-83. http://dx.doi.org/10.1080/13636820902820048

Palmer, R. (2005). Beyound the basics: Post-basic education training and poverty reduction in Ghana, Center for Africa Studies Post-Basic Education and Training Working Paper Series-No4.

Sonnenberg, K. (2012). Traditional Apprenticeship in Ghana and Senegal: Skills Development for Youth for the Informal Sector. Journal of International Cooperation in Education, 15(2), 93-105.

Straub, D. W., Boudreau, M-C. \& Gefen, D. (2004). Validation Guidelines for IS Positivist Research. Communications of the Association for Information Systems, 13, 380-427, https://aisel.aisnet.org/cgi/viewcontent.cgi?article=3243\&context=cais

Tutu Ayentimi, D., Burgess. J. \& Dayaram, K. (2018). Skilled labour shortage: a qualitative study of Ghana's training and apprenticeship system. Human Resource Development International, 1-18. https://doi.org/10.1080/13678868.2018.1447881

Udu, A. A. (2015). Apprenticeship Orientation and Performance of Micro-Businesses in Ebonyi State, Nigeria. European Journal of Biology and Medical Science Research, 3(6), 1-11. 
USAID (2021). Ghana National Apprenticeship Program Impact Evaluation: Effort, Incentives and Returns. https://www.usaid.gov/div/portfolio/ghana-national-apprenticeship

World Bank (2005). Reforming technical vocation and training in the Middle East and North Africa. Experience and challenges. European Training Foundation. The World Bank. 